\title{
The Social Group and Its Positive Effect on Social and Learning Skills the Child Earns
}

\author{
Valbona Keçia
}

\begin{abstract}
The education of children during the preschool age and social factors have a big impact on their preparation for life. Kindergarten and the group will prepare the child to become independent in his decisions and activities. In the preschool period, the child experiences a rapid development, especially in the emotional sphere. That is why one of the prior characteristics of the development is emotionality. Preschool children's feelings are so strong that they include the children's appearance. Children experience the objective truth very subjectively. All the knowledge and the behavior of the child depend on emotions, which we must take great care of in the kindergarten. We can use the child's emotions to stimulate in a positive way the motivation to learn. In cases where there is the emotionally convenient atmosphere for growth and development, the child has strong security and faith feelings to build relationships with the others. Starting the kindergarten is a challenge both for the mother and the child. The mother should be the child's biggest reliance to get used to the new environment. Socialization and the emotional development of the child cannot be separated. Winning and development of skills is in both individual and social nature. Cognitive processes do not function in the social emptiness.
\end{abstract}

\section{Keywords}

Preschool education, kindergarten, socialization, emotions, cognitive processes

Erik Erikson in his theory declares that, in the characteristics the child develops, there is a big importance in the environment he grows up and develops and in the people that surround him. According to him, in the early childhood, people and the environment that surround him have great importance because they set up the basis of their social-emotional and mental development of the child. The psychosocial theory makes us understand that, starting from the family circle and school up to the community, children will be affected and they will become dependent to this affection. The education of children during the preschool age and social factors have a big impact on their preparation for life. Kindergarten and the group where he will develop his activity, will prepare the child to become independent in his decisions and activities, to stimulate initiative, and to boost self-confidence (Cekani 2007).

In the preschool period, the child experiences a rapid development, especially in the emotional sphere. That is why one of the prior characteristics of the development is emotionality. Preschool children's feelings are so strong that they include the children's appearance. Emotions play an important role in their life. Children experience the objective truth very subjectively. All the knowledge and the behavior of the child depend on emotions, which we must take

aEuropean University of Tirana, Albania

\section{Correspondent Author:}

Valbona Keçi, 'Shoqeria Bashkimi' Street, Nr. 36, Durres, Albania 
great care of during the development of the educative process in the kindergarten. We can use the child's emotions to stimulate the motivation to learn and when this learning process is emotionally well-awaited, then the success of it is more than sure (Veseli 1999).

In cases where, in the family or kindergarten, there is the emotionally convenient atmosphere for growth and development, the child has strong security and faith feelings to build relationships with the others.

Starting the kindergarten is a challenge both for the mother and the child after a long attachment period with each other. The mother should be the child's biggest reliance to get used to the environment of the kindergarten. Socialization and the emotional development of the child cannot be separated because socialization depends on the scale of the social development, and additionally emotions are exclusively manifested through social interaction. Winning and development of skills is in both individual and social nature. Cognitive processes do not function in the social emptiness and the forms in which they are expressed are never separated from the social-cultural affections. Moreover, social factors cannot be thought separately from the individual cognitive processes. The theoretical points of view of Vygotsky and Piaget are positive to essential existence of internal and individual processes. These scientists, who have studied the development of the child during the age of 2-5 years old, have proved in their studies the fact that the children who have been naturally attached to their mother are more successful and show more control in works and choosing problems. Also, they are more responsible with their friends. The child's development process, which has started with the mother and family, is emphasized by the kindergarten and school, which approach him to a new group where he discovers new roles, models, behaviors, and values. The kindergarten is the transition environment between family and school. It marks the start of the organized way to learn for the child. It is essential that the entrance of the child in this stage and the getaway from the family environment are experienced without anxiety and insecurity, and without feeling alone. Sending the child in the kindergarten is a type of active autonomy. For a child who has stayed with his mother at home, going away from her for a certain amount of time interrupts the secure and privileged bond that keeps him attached to her, and the beginning is for sure hard. That is why it is the parents' and personnel's duty, in a strong collaboration with each other, to make the integration process easier for the child.

The kindergarten gives the child the life and integration in social groups, relieving him gradually from egocentrism. The cooperation that he realizes in the kindergarten and the integration in the social group affect the development of social attitudes, and contribute in the development of self-confidence and faith in others, in the development of friendship and formation of positive qualities. In the group, existence with each other and reciprocal relationships are very important. This makes that, the cognitive relations that are created affect positively the individual, adapting him with the others and creating the first friendships. The affective aspect of this perception and action in unity is the reciprocal identification between members of the group, identification of the existence of a common thing between them. Identification at this age is expressed in between feelings of solidarity and friendship, through the so-called "us".

The group is an entirety of dependent individuals, and it is a system, not a sum of people. The positivity of the kindergarten like a structure to be followed from children during early childhood is that in the kindergarten, there are also some other material structures that allow the realization of activities and interaction of children. Considering the group of children as a system, like a unity of people united in the same place and time, we can give some peculiarities about what the group of children in the kindergarten offers to an individual that comes from home. Children 
are modified mutually from the presence of others. The activities that are developed in the group of children are regulated from an inner organization in relation to the nature of the projects and activities. The group offers children a diversity of characters according to the nature of the children attending it. The environment modifies the group and the group modifies the environment. The more favored the formation of groups in the garden is, the more children grow up and develop during this age group.

Small children as basis of their activity have the game and they want to realize this game all together, because participation in the group, communication and relationships with others are their basic needs. Kindergarten children learn from their peers. In the success of the learning process in the kindergarten, a special importance is the creation of the group. The group should be treated like a complex system in development. A special importance is the environment and climate of the group where the child goes for the first time. Adaptation with the new world is not immediate and not always easy.

It is important that it is started with the formation of a good atmosphere of the group in the first days. It is important that the children are calmed down, and are eased down the tensions that can be lived, in order to integrate them with each other and encourage them to get to know each other. It is important that the children are involved in many games and activities and are stimulated in them the sense of cooperation (Zazzo 1969).

To children, group world is a system of obligations that have to do with the place they are assigned and rules they have to respect. Inside the group, he finds action models, behavior, and language that relate him with some aspects of the outside world. Also, inside the group, he meets those with whom he has pleasure staying and interacting, playing and having fun. The child in the group realizes the integration with other children, approaching his unit, social comparison with others, cooperation and competition, and intellectual, emotional, and social development. The child that grows up alone outside relationships with other children has significant shortcomings.

Hartup (1984) in his study showed that the relationship net that children create in the kindergarten is very important for their development. When growing up, children create their game and exchange circle, where boys tend to create bigger groups, whereas girls smaller ones. A big importance in stimulating children cooperation is even the teacher of the group, who should stimulate interaction and cooperation between children taking into consideration their interest, needs, and skills and even respecting their opinions.

The relationships that children create inside the group are dependent on the environment and climate there. The teacher in the group should play the role of the observer and participant in the group work. In the kindergarten, it is about an increase in the quality of different communication from the previous environments the child has frequented. In the stump of the communication scheme is the origin of pedagogical communication. In the kindergarten, teachers should be led from such principles like tolerance, stimulation of ethical behaviors in speaking and listening. The teacher listens carefully to the answers, so in a way is inside the situation she observes, so she is herself a member of the group.

First of all, the teacher should take into consideration that the process of learning and recognition is individual for each child. It is important to understand that in this age, it is much more important in communication rather than learning. The teacher should recognize the field of social psychology. The efficient direction of the group requires respect, love towards every child, and respect to his personality (Gjini 1999: 70-73).

The positive emotive development contributes to the organization of parties and different activities in the group. Children groups solve their problems better than a single individual, because they have more chances to 
get information from communication with each other. Groups are used to put into movement the brain and agility of each child (Veseli 1999).

The group affects positively in the creation of personal relationships inside the group. There is an improved control of themselves. Group work helps the child to better develop his self-control, because he learns to react to situations that are created from his peers or the teacher.

\section{SOCIAL SKILLS}

Group work teaches children the basic social skills, such as: compromise, communication, sympathy, and empathy. To children who do not frequent the kindergarten, a lot of these skills are not developed and they must learn them later than the others do. Stanford University's study in 2006 showed that children who have frequented the kindergarten in the three groups will have formed a good social character. The group affects positively in the learning process as well. Albert Bandura, who is known as the social learning theoretician, treated the case of the realization of learning under social life conditions. According to him, the individual can change his behavior while watching how the others act and react due to different factors. The biggest contribution of Bandura in his position as a behaviorist in 1971 has been in his trials to find a treatment of the process of learning basing on every theory about it. He states: "The human is a being which owns skills and gains conscious energy”.

Bandura's ideas have a great importance regarding the importance he gives to learning inside the group. According to him, learning inside the group is a special method of the teaching and learning process which includes pupils organized in groups that, through common involvement, aim to realize common products. Constant communication between group members, as well as involvements and individual contributes are some of the main characteristics of group work. To realize correctly and in the appropriate level learning inside the group, it is important that the themes the children like are well specified.

Preschool children enjoy learning. They are very curious. The stay of children in the kindergarten does not mean to be closed there, but to take active part in the group life and enjoy it a lot. The group helps the child to read with meaning. Group work helps children to find different ways to learn something, and also to learn from each other. A series of teaching methods have the group to successfully realize teaching, be it a big group or small group.

The two main methods are:

(1) Discussion in the big group as a teaching method;

(2) Learning in cooperation in the group.

The first is an appropriate methodology, because it stimulates the children's attention and helps them be active and free in discussions. This stimulates the child to talk and through talking to learn. Learning in cooperation is a successful strategy that is realized as a basic structure in the group. Each member of the group is responsible not only to learn what is being explained, but also to help the other members of the group to learn and create a success feeling. In the kindergarten, the process of learning is realized through the game. The game offers different possibilities that in the future will broaden both their social and emotional development. The game gives them the possibility to interact with the surrounding environment and allows children to understand the surrounding world. When the child has good social and emotional developments, this child is prepared to adapt to the school environment. These children find it easier to gain responsibilities and know how to deal with them. To them, going to school or another social group is more natural, calm, and welcomed.

\section{CONCLUSIONS}

During early childhood, the exposure of the child to the new experiences is very important. 
The group of peers helps the child grow and gain social and emotional abilities.

Passing the child from the family environment to the social one needs to be as natural and gentle.

The process of learning that is realized in collaboration and in continuous communication with each other in the group is a process that is accomplished with pleasure and love from the children.

Group games stimulate and develop the child to grow and become a successful individual.

\section{References}

Boyd, J., W. S. Barnett, E. Bodrova, D. J. Leong, and D. Gomby. 2005. Promoting Children's Social and Emotional Development Through Preschool Education. NIEER Policy Report.

Cekani, E. 2007. Methods According to the Fields of Development. Tirana: "Polis" Publishing.

Erikson, E. 1963. Childhood and Society. New York: W. W. Norton and Company.

Fulton, D. 2006. The Game and Learning During Early Childhood. London: David Fulton Publishers.
Gjini, F. 1999. The Social World of the Child. Elbasan: Sejko. Gjini, F. and A. Piluri. 2001. The Social World of the Child. Elbasan: Sejko.

Gray, K. J. and SOROS Foundation. 1998. Child's Development Philosophy. Tirana: Open Sociaty for Albania Foundation.

Hartup, W. W. 1984. "The Peer Context in Middle Childhood.” Pp. 240-282 in Development During Middle Childhood: The Years From Six to Twelve, edited by W. A. Collins. Washington, D.C.: National Academy Press.

Hoffman, D. 2002. The Education of Children. Standford, California: Standford University Press.

UNICEF. 2009. Inside of the Child. Tirana: World Vision.

Veseli, A. 1999. Preschool Pedagogy. Pristina: University of Pristina.

Vygotsky, L. S. 1978. Mind in Society: The Development of Higher Psychological Processes. Cambridge, Massachusetts: Harvard University Press.

Zazzo, R. 1969. Children During the Ages of 6 and 12 Years Old. Paris: Puf Editeur Editing and Publishing House.

\section{Bio}

Valbona Keçi, Ph.D., master teacher, Department of Pedagogy, European University of Tirana, Tirana, Albania; research fields: pedagogy, psychology, preschool education. 